\title{
Keep It in the Family - Right To Property and Family-Owned Businesses'Succession
}

\author{
Rita Lobo Xavier \\ Full Professor \\ Universidadecatólicaportuguesa - Faculty of Law \\ Catolica Research Centre for The Future of Law \\ Pedro Coutinho \\ Lecturer At Universidadeportucalenseinfante D. Henrique \\ Phd Student At Universidadecatólica Portuguesa - Faculty of Law \\ Catolica Research Centre For The Future of Law \\ Portugal
}

\begin{abstract}
In Portugal Family Business Represent 70\% - 80\% Of All The Enterprises, They Are Responsible For 50\% Of Employment And For 2/3 The GDP (Gross Domestic Product). Portuguese Constitution Recognizes Right To Property As A Fundamental Right And The Freedom To Dispose Of The Property Upon Death But There Are Many Legal Restrictions To Mortis Causa Transmission As Portuguese Legal System Grants A Part Of The Inheritance Assets To Some Members Of The Family Of The Deceased. Sooner Or Later, Family Enterprises Face The Problem Of Transition To The Next Generation And Researchers Have Pointed Out That The Lack Of Succession Planning May Lead To The Closure Of Family Business. The Disputes Among Heirs Disturb The Enterprise As Portuguese Law Has Not Yet Adopted A Solution Protecting The Continuance Of The Business In The Family When Several Heirs Claim Their Share Of The Enterprise And Require To Be Paid On Cash. Problems May Arise Even When One Heir Wants To Go On In The Business And Need To Pay The Others That Don'T Want To Stay In The Business. It Is Urgent To Create Rules To Facilitate The Family Businesses' Succession Which Is A Moment Very Difficult To This Kind Of Business. This Paper Enlightens The Specific Needs To Protect The Family Businesses And The Right Of Property Concerning Means Of Production, Aiming To Find Out Whether Under The Portuguese Constitution May The Family Businesses Have A Special Regime.
\end{abstract}

Key Words: Family-Owned Business - Right To Property - Succession Planning

\section{Introduction}

On The 25th Of April 1974, There Was In Portugal A «Revolution» Which Overthrew The Authoritarian Regime That Had Been Ruling For Over Four Decades And Changed The Government Into A Democracy, After A Transitional Period. The Present Constitution Was Adopted In 1976 And Had A Strong Ideological Content With Many References To Socialism And The Desirability Of A Socialist Economy, So It Was Controversial From The Start. The Constitution Urged The State To «Nationalize The Means Of Production And Abolish The Exploitation Of Man By Man». After Several Amendments, Many Economic Restrictions Were Removed And Much Ideological Language Eliminated. Important Changes Were Made, That Enabled The State To Privatize Much Of The Property And Many Enterprises Nationalized After The Revolution. At Present, The Portuguese Government's Party Is Socialist, And It Is Supported By A Coalition Of Left-Wing Radical Party And The Communist Party. There Is Still Much Prejudice Against «Capitalism» And Personal Accumulation Of «Richness» And Lack Of Understanding That Enterprises Create Wealth In A Free Market Economy. This Is Mostly Clear When People Criticize Family Business As Symbol Of «Capitalism» And Speak About Taxing Large Fortunes Or Wealthy Families, Without Emphasizing The Value Of Entrepreneur Activities. However, In Portugal Family Businesses Represent 70\% - 80\% Of All The Enterprises, They Are Responsible For 50\% Of Employment And For 2/3 The GDP (Gross Domestic Product) ${ }^{1}$. We Think That It Is Urgent To Create Rules To Facilitate The Family Businesses' Succession Which Is A Very Difficult Moment For This Kind Of Business.

\footnotetext{
${ }^{1}$ Marques, Ana Paula (coord.)Empresas Familiares da Região Norte, Mapeamento, retratos e testemunhos (2018) pp. 18-19.
} 
We Have A Deep Concern With This Matter And We Develop A Line Of Research That Aims To Changes Mentalities And To Create A Movement To Make Suitable Legal Rules, To Integrate And Mainstream These Ideas. It Seems That This Problem Is Similar In Many Countries, For Instance In Poland, Recently Overcoming A Collectivistic Regime, And Many Of Family Enterprises Are Now Facing The Problem Of Transmission To The Second Generation.

We Are Pleased To Be Able To Participate In This Conference In The Context Of The Celebration Of The Anniversary The Of The Universal Declaration Of Human Rights And To Share Our View On The Matter Of The Right To Property As A Fundamental Right And The State'S Duties In Relation To Its Social Function Especially When It Comes To Productive Assets As Is The Case With Family Businesses.

\section{Constitutional Background: The Right to Property in the Portuguese Constitution}

Like Most Constitutions, the Portuguese One Sets Private Property As A Fundamental Right, In Its Article 62. Although, For Historical Reasons, This Article Is Included In The Chapter That Deals With Economic, Social, And Cultural Rights (Rights That Require Legal Intermediation By The Legislator In Order To Be Fulfilled) Legal Doctrine Established From Early On That It Was In Fact A Fundamental Right Of Analogous Nature To The Freedom And Guarantee Rights (The Other Category Of Fundamental Rights, Which, To Put Things In A Simple Manner, Directly Applicable). As Far As This Work Is Concerned, It Is Important To Point Out That The Right To Property Includes Mortis Causa Transmission, And Also The Fact That The Constitution Itself Explicitly Mentions Restrictions To It, Such As Expropriation Grounded On Public Interest. Similarly, Public Initiative, Defined In Article 61, Is Also A Freedom And Guarantee Right Which Is, Significantly, Subject To A General And Explicit Restriction: The General Interest.

In Addition To These Express Limitations, It Must Also Be Said That A Global Perspective Of Fundamental Rights And Of The Constitutional Project Means That We Must Look At Each And Every One Them As An Integrant Part Of A System. Therefore, Fundamental Rights Must Be Applied In A Way That Ensures Compatibility Between All Of Them. ${ }^{2}$ Particularly Crucial, As Far As This Paper Is Concerned, Is The Compatibility Between Private Initiative And Private Property, On One Hand, And The Constitutionally Guaranteed Protection Of The Family, Which Includes Family Businesses.

\section{Right To Property And Social Dimensions - An Updated View On The Right To Property}

The Reference To The Explicit Restrictions To Private Property And Private Initiative Serves To Illustrate A Point That We Believe Is Clear About The Portuguese Constitution: It Establishes A Social Function For Property, I.E. It Sees Property Not As An Intangible And Absolute Right (As In The Liberal State Paradigm) But As Something That Should Be Put To Use For The Common Good.

While The Construction Of A Theory Around The Social Function Of Property Is Largely Doctrinal, Several Constitutional Norms Lend Support To This Theory. In Support, Therefore, Of This Theory, We Can Mention, Among Many: Article 81 C), Which Tasks The State With Ensuring Full Use Of Productive Forces; Article 86/1, That Refers That He State Should Incentivise Corporate Activity, In Particular Small And Medium Enterprises; And Article 88, Which Gives The State Extensive Powers Regarding Putting To Use Abandoned Means Of Production.

\section{Inheritance Law and Legal Restrictions to Mortis Causa Transmission}

The Portuguese Legal System Grants A Part Of The Inheritance Assets To Some Members Of The Family Of The Deceased. The «Legítima» Is A Part Of The Inheritance Of Which The Deceased May Not Deprive An Heir. This Part Is Inviolable And Deprivation Can Occur Only Under Conditions Of Disinheritance, Unworthiness To Inherit Or Disclaimer Of Inheritance ${ }^{3}$.

\footnotetext{
${ }^{2}$ An idea contained in article $18^{\circ}$ of the Constitution, which states that the restriction of freedom and guarantee rights is possible, but only insofar as that restriction is necessary to protect and safeguard other constitutionally protected rights or interests..Cfr. Gomes Canotilho and Vital Moreira (2007), pp. 388.

${ }^{3}$ In the European context the protection of family is achieved whether by the so-called inheritance reserve or by the legitim. Mariusz Zalucki (2015) describes the essential characteristics of the reserve systems and the legitim systems. In spite of the semantics, the Portuguese legítima is rather a kind of «reserve» than a «legitim».
} 
When It Comes To Planification, It Means There Is A Disposable Part (Freely Disposable) And A Compulsory Part Which Must Be Granted To Heirs Specified By The Civil Code (Children, Husband/Wife, Parents/Ascendants, In The Absence Of Descendants) ${ }^{4}$.

Under Portuguese Law, The Compulsory Portion Of The Deceased's Estate Due To Some Heirs Is Not Only A Credit - As It Is In Germany, For Instance - But The Right To Share The Deceased'S Estate.These Heirs Are Entitled To A Part Of The Assets Of The Deceased And Have A Legal Right That Arises With The Death To Claim Against Dispositions Made During His/Her Lifetime. Portuguese Law Allows The Heirs To Reduce The Dispositions Made By The Deceased (Including Donations) To Guarantee The Value Of The «Legítima».

This Judicial Claim To Reduce The Donations(«Ação De Redução Das Liberalidadesinoficiosas»Must Take Place Within Two Years After The Acceptance Of The Inheritance. Donations Are Reduced Starting With The Most Recent And Heirs Must Account For The Value They Have Already Received By Gifts(Accounting Obligation $)^{5}$.

Despite The Essential Characteristics Of Reserve, The Portuguese System Has Some Features Of The Legitim Systems, As When The Deceased Has Disposed Some Assets During His/Her Lifetime That Affects The Reserve, After The Inheritance's Opening, The Heirs Are Entitled To A Claim For Monetary Compensation And Not A Right In Rem, As It Is Generally The Case In The Reserve Systems.The «Legítima» Is A Restriction On The Freedom To Dispose Of The Property In Case Of Death That Is Not Adapted To The Current Needs Of Society, Where The Right To Dispose Of The State In The Event Of Death Is Emphasized As A Core Value. There Is A Trend To Liberalize The System ${ }^{6}$.

\section{Family-Owned Businesses' Succession Environment And Specific Requirements}

Sooner Or Later, Family Enterprises Face The Problem Of Transition To The Next Generation. As The Surviving Spouse And The Descendants ${ }^{7}$ Have The Right To Share The Deceased'S Estate,If Only One Of The Children Wants To Join The Family Business And The Others Claim For A Part Of It, The Risk Is Forced Sale In The Event Of Death. Problems May Arise Even When One Heir Wants To Go On In The Business And Needs To Pay The Others That Don'T Want To Stay In The Business. The Problem Is The Heirs Must Be Compensated And That Often Happens Through Drainage Of Capital From The Company.Family Entrepreneurs Are Forced To Arrange The Ownership Transition Of The Family Business But Proper Estate Planning Is Difficult Andresearchers Have Pointed Out That The Lack Of Succession Planning May Lead To The Closure Of The Business $^{8}$.Some Tools Are Used To Plan Business Succession. Portuguese Law Allows The Inclusion Of Transfer Restrictions As Clauses Of The Company's Contract Or Make Shareholder'S Agreements ${ }^{9}$. Often, Ownership Transition Confronts The Entrepreneur With A Dilemma: Selling The Company To Someone Outside The Family Or An Interfamily Succession Arrangement, For Instance Through A Gift Of Shares Or A Will.However,

Under Portuguese Law Succession Agreements Are Prohibited. The Disputes Among Heirs Disturb The Enterprise But Portuguese Law Has Not Adopted A Solution Protecting The Continuance Of The Business In The Family When Several Heirs Claim Their Share Of The Enterprise And Require To Be Paid On Cash. In Other Words, Under Portuguese Law, A Family Business Is Treated Just Like Any Other Asset, Failing To Address The Specific Requirements Of Family Enterprises. If These Are To Remain Stable And Successful, Something Which Is In The Interest Of The Whole Community, Then They Must Remain Within The Ownership Of The Family, As That Is Part Of Their Genetic Identity. Adaptation Of The Legal Instruments Is Required For This To Happen.This Has Happened In Other Jurisdictions. In Order To Facilitate The Transfer Of Family Businesses, French, Spanish And Italian Succession Rules Were Changed ${ }^{10}$. Italian Succession Rules Have Been Reformed, Introducing The So Called «Patto Di Famiglia».

\footnotetext{
${ }^{4}$ See Arts. $2156 .^{\circ}$ and $2157 .^{\circ}$ of the Portuguese Civil Code. The compulsory part may be $1 / 2,1 / 3$ or 2/3 of the inheritance, according to the heirs that are intitled to it.

${ }^{5}$ See Arts. $2168 .^{\circ}-2178 .^{\circ}$ of the Portuguese Civil Code.

${ }^{6}$ XAVIER (2017), p. 91.

${ }^{7}$ The ascendants only have the right to a part of the inheritance together with the surviving spouse when there are no descendants.

${ }^{8}$ XAVIER (2017), p.36

${ }^{9}$ XAVIER (2017), pp. 45-48.

${ }^{10}$ XAVIER (2017), pp. 77-89. 
Under The New Articles Of The Civil Code, «Patto Di Famiglia» Is A Contract Through Which, With Compatibility With The Rules Governing Family Firms And In Obedience To The Different Company Types, The Entrepreneur Transfers The Firm, Wholly Or Partially, And The Stockholder Transfers, Wholly Or Partially, His Stocks To One Or More Descendants. Management Rules Throughout The Generational Change.All The Descendants And The Spouse, Who Have A Right To A Part Of The Inheritance, Must Participate, And They Lose The Chance To Bring Later Any Claim For Reducing The Donation («Azione Di Riduzione») ${ }^{11}$.

\section{Family-Owned Businesses Succession - Ownership Transition Tools}

Succession In Family-Owned Businesses Is Not Exactly A New Problem. As Such, The Law Already Provides Some Tools That Have Been Traditionally Used In Planning For The Future In Such Enterprises. Among These Are The Will, The Gift Of Shares, Agreements Between Shareholders And Transfer Restriction Clauses. However All Of These Instruments Face A Severe Limitation: They All Require, In Some Way Or Another, That The Person Who Will Succeed In The Management Of The Business Monetarily Compensate The Others. This Becomes, Naturally, A Problem When We Are Talking About Family-Owned Businesses That Are, Nonetheless, Of A Significant Dimension And Where The Business Itself Is The Main And Almost Only Asset Of The Family.

\section{Family-Owned Businesses' Succession - Tools, But Not For Everyone}

As A Result Of The Limits Of Traditional Succession-Planning Tools, New Legal Tool Have Appeared In Recent Years. The Appearance Of These New Instruments Threatens, However, To Create A Material Inequality Within Family-Owned Businesses. This Is So Because The Difference In Size Will Determine The Availability Of These New Instruments. Therefore, An Inequality Is Created Between Family-Owned Businesses That Are Smes (Small And Medium Enterprises) And Those That Are Not. This Inequality Becomes Clear When We Think Of The New Instruments. We Are Referring To The Adoption Of A Certain Legal Form (Such As The Holding, A Form Not Available In Every Jurisdiction), The Possibility Of Choosing A Different Jurisdiction, Where Legal Constraints Are Smaller, And To The Adoption Of A Trust, Traditionally A Non-Existent Possibility In Civil-Law Jurisdictions (But Now Available In A "Continental" Version In Italy And France, Specifically Designed To Address The Concerns Of Family Businesses).As We Can See, The Availability Of These Instruments Is Contingent On The Possibility Of The Companies To Practise "Forum Shopping". And While, Particularly In Europe, This Possibility Is, In Theory, Open To Every Company, In Reality The Possibility Of "Hopping" Jurisdiction In Order To Benefit From A Specific Legal Regime Will Only Appeal To Larger-Sized FamilyOwned Businesses.

Therefore, This Leaves The Smaller Family-Owned Businesses, The Ones Most In Need Of Legal Protection, Stuck With The Traditional Planning Instruments, Whereas The Larger Businesses, Less In Need Of Protection, Benefit From The More Advanced Succession-Planning Instruments. Given The Particular Importance Of SME Family Businesses We Believe That This Inequality Should Be Corrected And Alternatives To Current Situation Found.

\section{Keep It In The Family: The Enterprise Agreement- A Proposal}

Having In Mind That Family Businesses Aren`T Similar To Other Assets Because Of The Very Important Values Associated To Its Unity And Stability Even In Context Of Ownership Transition, And Bearing In Mind What Was Said About The Social Function Of Property, We Think That A Succession Agreement In This Matter Should Be Admitted. It Is Necessary To Accept A Mortis Causa Contract, That Would Be An Exception To The Prohibition Of Succession Agreements And Respects The «Legítima» Of The Heirs ${ }^{12}$.

\section{Keeping It In The Family - Conclusions}

Keeping It In The Family Means:

- Special Protection Of The Family Business In Case Of Mortis Causa Transmission

- This Special Protection Includes Rules To Facilitate The Continuity Of The Business Avoiding The Fragmentation In Case Of Heir's Disputes

- Family Entrepreneurs Should Be Allowed To Arrange The Ownership Transition Of The Family Business

\footnotetext{
${ }^{11}$ Fusaro, Andrea (2011) and (2015); Loconte, Stefano (2016).

${ }^{12}$ XAVIER and COSTA (2018)
} 
- To Achieve This Target A Change In Inheritance System Is Required: The Heirs Who Don'T Want To Stay In The Business Must Be Allowed To Renounce Having A Share In Order To Facilitate Ownership Transmission Before The Entrepreneur's Death.

\section{References}

MARQUES, Ana Paula (Coord.) Empresas Familiares Da Região Norte, Mapeamento, Retratos E Testemunhos 2018 (ISBN 978-989-20-8693-4).

CANOTILHO, J.J. Gomes, And MOREIRA, Vital, Constituição Da República Portuguesa Anotada, Vol. I, Coimbra, Almedina, 2007.

FUSARO, Andrea «Uno Sguardocomparatistico Sui Pattisuccessor E Sulladistribuzionenegoziatadellaricchezza D'impresa» In Ricerchegiuridiche II, 1, Suplemento, 2010 (353-376).

FUSARO, Andrea, «Transferring Business Ownership In Italian Family Enterprises» In STAMM, Isabel Et Alii (Ed.) In Doing Succession In Europe, Generational Transfers In Family Businesses In Comparative Perspective, Schulthess, Zürich - Basel - Geneve, 2011 (315-321).

FUSARO, Andrea, «Company Succession In The Latin Law Tradition Using The Example Of The Italian Legal System» In S. Kalss (Ed.), Company Law And The Law Of Succession, Iuscomparatum - Global Studies In Comparative Law 5, Springer International Publishing, Switzerland, 2015 (289-304).

LOCONTE, Stefano (2016) - «I Pattidifamiglia», In Strumentidiplanificazione E Protezionepatrimoniale, 2 Ed., Wolterskluweritalia.

XAVIER, Rita Lobo, Sucessão Familiar Na Empresa, A Empresa Familiar Como Objeto Da Sucessão Mortis Causa, Católica Editora, Porto, Portugal, 2017

XAVIER, Rita Lobo E COSTA, Simone Oliveira, «Relevância Dos Pactos Sucessórios Na Sucessão Na Empresa Familiar: O Pacto De Empresa»In Roadmap Para Empresas Familiares: Mapeamento, Profissionalização E Inovação, Edição Docentro Interdisciplinar De Ciências Sociais (CICS.NOVA) - Polo Da Universidade Do Minho (CICS-Uminho), Outubro 2018 (E-Book DOI Https://Doi.Org/10.21814/1822.56256; ISBN 978.989.99768.2.5 2018) (25-42).

ZALUCKI, Uniform European Inheritance Law, Myth, Dream Or Reality Of The Future, AFM Publishing House, Krakow, 2015. 